were represented in each herd. Heterosis effect was estimated by the relative superiority of the average of the two reciprocal crosses relatively to the average of the parental breeds. The heterosis effect was : 3, 4, is and 6 p. Ioo respectively for litter size at birth, at weaning, weaning conception-interval and numerical productivity of the sow (number of piglets weaned/sow/year).

Differences between reciprocal crosses were low. The weaning-conception interval was almost independent of the litter size $(r=-0.03)$ and very slightly associated with lactation length $(r=-0.06)$.

\title{
Productivity of sows in France as afiected by housing eonditions, equipment of farrowing pens and age at weaning
}

\author{
A. Aumaitre, J. M. PEREZ and J. ChauveL* \\ Station de Recherches sur l'Élevage des Porcs, I. N. R. A., C. N. R. Z., \\ 78350 Jouy en Josas \\ * Institut technique du Pore, \\ 149, rue de Bercy, \\ 75579 Paris Cedex 12
}

Two series of data were used in this study : the first one concerned performance recordings of 247462 litters of piglets born between 1965 and 1973 in all regions of France and the second one proceeded from the results of the National computerized programme for analysis of on-the-farm sow records concerning performances of 217 I30 litters born between 1969 and 1974 .

Mean losses of piglets (2.13 piglets lost per litter between birth and weaning, calculated from I 35508 data) represent 19,8 p. Ioo of the total number of animals born (Io, 8 piglets/litter). These losses reach a maximum in badly heat conditioned farrowing houses (2.27 per litter in huts heated with lamps, 2.I 7 in farrowing houses without lamp heating and 2.03 in farrowing houses heated with lamps). Among all devices used for the internal arrangement of the pens, the farrowing rail appears to be the less favourable system (2.30 piglets lost) and that according to which the sows are blocked or attached, the most favourable one (2.03 piglets lost per litter). These results emphasize the importance of the efforts to be made with respect to internal arrangement and thermic protection of farrowing houses.

The mean age at weaning of the piglets has regressed from 6I days in 1965 to 38 days in 1973 , $i$. e. a mean reduction of 3.7 days per year. In addition, for the period I969-1974 taken as a whole, one fourth of the litters observed was weaned before $3 \mathrm{r}$ days, indicating a very marked trend towards very early weaning of piglets in the practice of French pig production. This trend is particularly clear in large herds (Ioo sows and more).

The interval between weaning and conception is generally abnormally long (22 days). This interval is excessively lengthened (45 days) in the case of too early weaning before ro days or too late weaning after the age of 50 days (I I p. Ioo of the sows are not fertilized 2 months after weaning). On the other hand, the percentage of fertilized animals is days after weaning varies little (68 p. roo on an average) for weanings between 16 and 45 days.

The age at weaning has a very small (but active) influence on the litter sist : thus, the mean number of weaned piglets increases with the age at weaning at the previous cycle (the number 
varies from 8.90 to 9.07 when the age at weaning passes from $16-20$ days to $4 \mathrm{I}-45$ days). This variation in the number of piglets produced per litter (o.17 piglets) is almost neglectable as compared to the loss of numerical productivity (number of piglets weaned/sow/year) consecutive to a 30 days-lengthening of lactation and of the interval between two farrowings. Thus, after $2 \mathrm{I}$ days of lactation, (the optimum being located between $I 7$ and 22 days), any delay of ro days at weaning and/or at conception leads to a loss of annual productivity of the sow of 1.4 piglets. Consequently early weaning appears to be an efficacious technique for improving the productivity of French sow herds.

\title{
I. - THE GROWING-FINISHING PIG NUTRITION
}

\section{Reduetion of protein level and supplementation with lysine of growing-finishing pig diets}

\author{
J. LOUGNON and D. MAZOYER* \\ A.E.C., Sté de Chimie Organique et Biologique, \\ 03600 Commentry \\ * Sté ORGEX, \\ 42620 Saint-Martin d'Estreaux
}

Reduction of the incorporation rate of soyabean oil-meal into the diets of growing-finishing pigs was examined in two experiments.

The first experiment was achieved on 5 groups of females weighing between I 8 and Ioo $\mathrm{kg}$. In the first group $(\mathrm{H})$, the animals were given a "growing " feed ( 19 p. Ioo of soyabean, 17.7 p. Ioo of crude protein, $0.86 \mathrm{p}$. Ioo of lysine), then a "finishing " feed (I 5 p. Ioo of soyabean, I6.0 of crude protein, 0.74 of lysine). Diets containing $\mathrm{I}_{4}$ then Io $\mathrm{p}$. Ioo of soyabean (group $\mathrm{M}$ ) gave slightly lower performances (weight gain, feed conversion). The supplementation of those diets (group ML) with lysine allowed to reach the same performances as in the reference group. A new reduction of the soyabean content ( 9 then 5 p. Ioo) (group B) resulted in a significant fall in the performances, which was stopped by the addition of lysine (group BL). This supplementation with lysine improved the body composition without rendering it as satisfactory as in the pigs of the $\mathrm{H}$ group.

The second experiment, achieved on a larger number of animals, castrated males and females, confirmed the preceding results, the performances of the BL group being equal to those of the $\mathrm{H}$ group. 